\title{
Linguodídactica KKIII
}

DOI: 10.15290/lingdid.2019.23.06

канд. пед. н., доц. Марина Геннадьевна Гец

Минский государственный лингвистический университет

Кафедра лингводидактики и методики обучения иностранным языкам

тел. +375172 2947491

e-mail: mgg@tut.by

ORCID ID: https://orcid.org/0000-0002-3939-0494

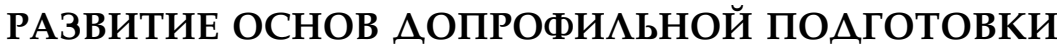 И ПРОФИАЬНОГО ОБУЧЕНИЯ НА ПРИМЕРЕ ЯЗЫКОВОГО ОБРАЗОВАНИЯ}

\author{
ABSTRAKT \\ SZKOŁY I NAUCZANIE PROFILOWANE NA PRZYKŁADZIE KSZTAŁCENIA JĘZYKOWEGO - \\ ZAŁOŻENIA PRZYGOTOWAWCZE
}

Autorka omawia historię i etapy rozwoju idei edukacji profilowanej na przykładzie kształcenia językowego na Białorusi. Analizie poddano procedurę tworzenia klas profilowanych w ogólnokształcących szkołach średnich, w tym w gimnazjach i liceach. Przykłady współczesnego profilowanego nauczania języków obcych ilustrują potrzebę nadania profilowaniu statusu innowacyjnego i nieodwracalnego procesu.

Słowa kluczowe: kształcenie językowe, nauczanie profilowane, zajęcia fakultatywne, klastry, podejście oparte na kompetencjach

\section{ABSTRACT \\ DEVELOPMENT OF PRELIMINARY FIELD ORIENTED BASICS AND SUBJECT ORIENTED INSTRUCTION BY MEANS OF FOREIGN LANGUAGE TEACHING EXAMPLE}

The author looks at the stages of subject oriented instruction development in the context of language and linguistic education. The debatable issues of subject oriented classes curricula and university specialty programmes are raised. The examples are set to confirm the necessity of making these innovative processes irreversible and sustainable.

Key words: language education, subject oriented instruction, clusters, elective courses, competence approach

Современное образование, в том числе языковое, нацелено на развитие у обучаюшихся качеств и характеристик представителей демократической культуры, готовности к информационному обмену в динамичном коммуникативном пространстве. Одна из современных образовательных тенден- 
ций заключается в обеспечении синхронизации протекания этих процессов, закладывающих основы осознанного выбора профиля деятельности и эффективного ее осушествления, формирования и развития жизненно необходимых компетенщий будущего.

Независимая система образования в Республике Беларусь начала создаваться в 1991 году, когда был принят закон об образовании, согласно которому организовывались гимназии, лицеи, школы (классы) с углубленным преподаванием ряда предметов. В гимназии и лищеи принимали на конкурсной основе, определявшейся советом учебного заведения на основании примерного положения о гимназии и лищее от 15 июля 1992 года. Активно разрабатывались новые учебные планы, программы, учебники с национально ориентированным содержанием. Первый эксперимент по созданию моделей профильных классов в сельских школах был проведен в 1994 году в Глубокском районе Витебской области.

Начиная с 1995 года создаются учебные планы, рассчитанные на разное количество часов для базового, углубленного и повышенного уровней. Последний рассматривался как основа для профильных классов в средней школе. С 1996 года разрабатывалась, а в 1998 году началась реформа школы, согласно которой школы должны были перейти на 12-летнее обучение с профильным обучением в 10 и 11 классах (первым классом был нулевой) после окончания 10-летнего базового образования. Она была отменена в 2008 году, не состоялось ни одного выпуска.

С этого года происходит отделение белорусского образования от советского. Профильное обучение заменяется факультативами, обучение в лицеях становится возможным в 10 и 11 классах. Факультативные занятия по иностранному (английскому) языку активно внедрены в практику современных учреждений обшего среднего образования (УОСО) и организованы по обширному комплексу направлений лингвистических исследований и смежных с лингвистикой наук. Например, факультатив «Практикум по чтению» в 5-6-х классах, «Коммуникативная грамматика» для 9 класса УОСО с белорусским и русским языками обучения ${ }^{1}$, «Зарубежная литература», «Основы перевода», «Страноведение Великобритании и США», «Культура речевого обшения». В лищеях осуществляется обучение, ориентированное на будущую профессию. В нем учащиеся могут до сих пор выбирать для себя направление, «профиль» будущей специализации. Эти положения были заложены в 1988-1991 годах.

1 Электронная платформа к факультативному курсу по английскому язьку «Коммуникативная грамматика», [online], https://sites.google.com/site/learnenglishmyenglishlab/home, [dostęp: 08.10.2018]. 
Еще одним шагом на пути профилизации школы должны были стать кластеры. Несколько лет назад начали создаваться республиканский и региональные учебно-научно-инновационные кластеры непрерывного педагогического образования, открываться филиалы кафедр учреждений высшего образования в УОСО, гимназиях и лицеях. Кластер объединяет региональные учреждения образования, относящиеся к различным уровням, научные и научно-методические организации, иные учреждения и организации, общественные объединения, добровольно взаимодействующие на договорной основе, участвуюшие в формировании инновационных подходов к педагогическому образованию и обеспечивающие практическое использование этих подходов при подготовке педагогов.

Целью кластера является интеграция и развитие учебно-научно-инновационного потенщиала входяших в кластер учреждений и организаций для подготовки педагогов, обладающих высоким уровнем гражданственности, культуры и профессиональной компетентности, способных создавать новые знания в сфере профессиональной деятельности, разрабатывать и внедрять инновационные образовательные программы и технологии ${ }^{2}$.

Основными задачами регионального кластера являются:

- разработка модели развития непрерывного педагогического образования в регионе;

- координация деятельности учреждений образования региона; выявление проблемных полей и тематики приоритетных психолого-педагогических исследований в сфере образования;

- координация научно-исследовательской деятельности в области педагогического образования; систематическое проведение региональных методологических семинаров в сфере педагогического образования;

- создание информационной базы данных об имеющихся в регионе научно-педагогических школах и инновационном опыте образовательной практики в области педагогического образования;

- обеспечение мобильности профессорско-преподавательского состава в целях повышения качества подготовки кадров в сфере образования;

- формирование эффективной системы непрерывного педагогического образования с учетом особенностей региона;

- поиск и подготовка мотивированных абитуриентов на педагогические специальности; усиление практико-ориентированности профессиональной подготовки педагогов с использованием региональных баз педагогических практик, имеющих опыт инновационной деятельности;

2 Педагогические кластерь в Беларуси, [online], http://mir.pravo.by/library/news/different/pedklastery/, [dostęp: 09.10.2018]. 
- обеспечение постоянной обратной связи с заказчиками педагогических калров;

- обобщение и распространение регионального передового научно-педагогического опыта ${ }^{3}$.

Организационное обеспечение деятельности регионального кластера осуществляет ведущее учреждение высшего образования. $\Delta$ ля обеспечения деятельности кластера создается региональный Координационный совет по вопросам непрерывного педагогического образования, являющийся постоянно действуюшим совещательным и экспертно-консультативным органом обшественного самоуправления.

Новая модель образования, реализуюшая приншипы относительной завершенности содержания образования на II ступени и профильного обучения на III ступени общего среднего образования в контексте компетентностного подхода, была введена в сентябре 2015 года 4 .

Качественное обновление и совершенствование профессионального образования недавно получило новый импульс. В настоящее время прорабатываются возможности внедрения в нашей стране дуальной системы подготовки кадров, определяются организации, заинтересованные во внедрении дуального образования» ${ }^{5}$ “ «уальное образование - это вид обучения, при котором студенты (учашиеся) приобретают теоретические знания в университете (колледже, профессиональном лицее), а практические - на рабочем месте на предприятии» ${ }^{6}$.Все обучение, включая теоретическую часть, оплачивается предприятием. Ауальные стуленты (учащиеся) получают зарплату с первого рабочего дня, причем как во время практики, так и во время теоретического обучения, - перечисляют плюсы дуального образования в Министерстве образования. Заявки на дуальные программы подаются абитуриентами на предприятия и фрирмы, как правило, за год до окончания школы. После получения места и подписания договора подаются документы на выбранную специальность в университете (коллеАже, профессиональном лицее) $\gg^{7}$.

По данным Министерства образования, всего в Германии сушествует около 1500 дуальных программ высшего образования, что «соответству-

3 Там же

4 Нормативно-методическое обеспечение профильного обуиения, [online], http://adu.by/?p=5150, [dostęp: 02.10.2018].

5 Б.А. Железко, В.Г. Кобзев, О.А. Синявская, Ауальное образование и ИТ предпринимательство как факторы инновационного развития образования в области информационньх технологий, [online], http://www.miu.by/userfiles/file/News/1-2018/Zhelezko-2017.pdf, [dostęp: 28.12.2018].

6 Там же.

7 Там же. 
ет примерно 4\% всех специальностей в стране». «В общей сложности как минимум 12 месяцев приходятся на практику на предприятии, в некоторых случаях практическая часть составляет 18 месяцев и больше» ${ }^{8}$. «Время практики распределяется по договоренности между университетом (колледжем, профессиональным лицеем) и заказчиками подготовки специалистов. В целом обучение Алится 4-5 лет»9.

«Пока неизученным остается механизм привлечения организаций-заказчиков кадров, независимо от формы собственности, к участию в софинансировании подготовки калров, а также механизмы стимулирования организаций на инвестирование средств в подготовку, переподготовку, повышение квалификации спещиалистов, рабочих, служащих, укрепление материально-технической базы учреждений образования» ${ }^{10}$. Внедрение дуального образования в практику подготовки учителей и преподавателей иностранного языка будет способствовать закреплению педагогических кадров в регионах. Молодым специалистам-лингвистам необходимо чувствовать заинтересованность со стороны администрации УОСО и района, востребованность собственных углубленных знаний и компетенщий.

С одной стороны, университеты получают возможности расширения перечня профилей подготовки специалистов. С другой стороны, заинтересованные стороны в виде заказчиков кадров, присутствуя на государственных экзаменах, распределении выпускников, внося коррективы в учебные программы производственной практики студентов, оценивают их профессиональную готовность и непосредственно обновляют и совершенствуют их подготовку. Современный преподаватель-лингвист должен быть качественно подготовлен к осуществлению профильного обучения иностранным языкам.

В соответствии с моделью профильного обучения для изучения учебного предмета «Иностранный язык» на III ступени отводится 175 часов (на базовом уровне 105 часов) ${ }^{11}$. Аля повышенного уровня изучения иностранного языка разрабатываются учебно-методические комплексы и контрольные задания, в том числе электронные. Проиллюстрируем углубление содержания языкового образования на примере одной темы, изучаемой в 10-х классах (см. таблицу 1) ${ }^{12}$ :

8 Там же.

9 Там же.

10 Там же.

11 Нормативная база организации обуиения иностранным языкам, [online], http://adu.by/ru/home page/prof-oby-1/inostrannyj-yazyk.html, [dostęp: 01.10.2018].

12 Электронные средства обуиения по английскому языку (профильньле классь), [online], http://www.adu.by/ru/uchitelyu/sovremennye-sredstva-obucheniya-i-ikt-v-obrazovanii.html, [dostęp: 08.10.2018]. 
Таблица 1. Сравнительный анализ тематических ситуаций «Молодежь и обшество»

\begin{tabular}{|c|c|c|}
\hline № & Базовый уровень & Продвинутый уровень (профильные классы) \\
\hline 1. & 11 ч. & 20 ч. \\
\hline 2. & \multicolumn{2}{|c|}{$\begin{array}{l}\text { Артикль с названиями молодежных организаций } \\
\text { Complex Object (рецептивно для базового уровня) }\end{array}$} \\
\hline 3. & Молодежь и общество & Молодежь и общество \\
\hline 4. & Молодежные организации Великобритании & $\begin{array}{l}\text { Молодежные организации Великобритании } \\
\text { (2 ч.) }\end{array}$ \\
\hline 5. & Молодежный парламент Великобритании & Молодежный парламент Великобритании \\
\hline 6. & Молодежные лозунги & Молодежные лозунги \\
\hline 7. & Чирлидинг - вид спорта или развлечение & Чирлидинг - вид спорта или развлечение \\
\hline 8. & & Чирлидинг в Беларуси \\
\hline 9. & САелай свой выбор & САелай свой выбор (2 ч.) \\
\hline 10. & $\begin{array}{l}\text { Молодежные организаџии Республики } \\
\text { Беларусь (2 ч.) }\end{array}$ & $\begin{array}{l}\text { Молодежные организации Республики } \\
\text { Беларусь (2 ч.) }\end{array}$ \\
\hline 11. & $\begin{array}{l}\text { Общественное объединение «Белорусский } \\
\text { республиканский союз молодежи» }\end{array}$ & $\begin{array}{l}\text { Общественное объединение «Белорусский } \\
\text { республиканский союз молодежи» }\end{array}$ \\
\hline 12. & Обязанности бойскаута & Обязанности бойскаута \\
\hline 13. & & $\begin{array}{l}\text { Проблемы молодежи в современном } \\
\text { обществе (2 ч.) }\end{array}$ \\
\hline 14. & & Молодежные организации в моей школе \\
\hline 15. & $\begin{array}{l}\text { Мое участие в деятельности молодежной } \\
\text { организации/объединения }\end{array}$ & $\begin{array}{l}\text { Мое участие в деятельности молодежной } \\
\text { организации/объединения }\end{array}$ \\
\hline 16. & & А ты уже стал волонтером? \\
\hline 17. & & $\begin{array}{l}\text { Участие молодежи в общественной жизни } \\
\text { страны (2 ч.) }\end{array}$ \\
\hline
\end{tabular}

Как видно из таблищы, общим требованием для обоих уровней остается изучение одного и того же грамматического явления, вероятно, с большим акцентом на систематизацию и обобшение грамматических средств. Более подробно рассматриваются проблемы молодежной политики и участие молодежи в жизни современного общества, молодежные организации, в том числе, в конкретной школе, волонтерское движение, происходит консолидация лексического материала посредством варьирования ситуаций его использования.

К другим изменениям в учебной программе по иностранным языкам Аля профильного изучения можно отнести увеличение спектра коммуникативных задач и более высокие требования к языковой, речевой и социо- 
культурной составляющим коммуникативной компетенщии. В соответствии со шкалой общеевропейских компетенций владения иностранным языком на базовом уровне предполагается достичь А2 (элементарное владение), на повышенном уровне - В1-В2, в том числе при самостоятельном овладении. К коммуникативным задачам рассказать / сообщить о..., расспросить о ..., посоветовать / рекомендовать, выразить мнение о ... и аргументировать его, согласиться / не согласиться с мнением о ... добавлены следуюшие: охарактеризовать, сравнить, выяснить, прокомментировать, аргументировать точку зрения / принятое решение ${ }^{13}$.

Всесторонняя реализация потенщиала учебного предмета «Иностранный язык» подразумевает совершенствование структуры интеллекта учащегося, развитие мыслительных операций и эмоционально-волевых качеств личности учашегося, погружение в лингвокультуру Аля воспитания уважительного и толерантного отношения к культуре и народу страны изучаемого языка, овладение универсальными, метапредметными, обшими умениями, которые являются необходимым условием развития и социализации субъектов межкультурного общения.

Эволюционное развитие профильного обучения учебным предметам в УОСО и новотипных учреждениях образования согласуется с идеями конщепщии непрерывности обучения. Обеспечение мобильности и гибкости подготовки специалистов, в том числе в сфере языкового образования, является требованием к ним заказчиков и потребителей. Создание кластеров, внедрение дуальной модели, расширение допрофильной полготовки и углубление профильного обучения по-разному, но целенаправленно диверсифищируют содержание, формы, методы и образовательные технологии.

\section{Библиография}

Electronnaya platforma $k$ fakultationomu kursu po angliiskomu yazyku, «Kommunikativnaya grammatika», [online], https://sites.google.com/site/learnenglish myenglishlab/home, [dostęp: 08.10.2018].

Pedagogicheskiye klastery $v$ Belarusi, [online], http://mir.pravo.by/library/news/diffe rent/ped-klastery/, [dostęp: 09.10.2018].

Normationo-metodicheskoie obespecheniye profilnogo obucheniya, [online], http://adu.by/ ?p=5150, [dostęp: 02.10.2018].

13 Авторские курсы И.В. Зубрилиной, [online], http://e-vedy.adu.by/course/index.php?categoryid=67, [dostęp: 04.10.2018]. 
Zhelezko B.A., Kobzev V.G., Siniavskaya O.A., Dualnoye obrazovaniye i IT predprinimatelstvo kak factory innovazionnogo razvitiya obrazovaniya $v$ oblasti informacionnyh tehnologiy, [online], http://www.miu.by/userfiles/file/News/1-20 18/Zhelezko-2017.pdf, [dostęp: 28.12.2018].

Normationaya baza organizacii obucheniya inostrannym yazykam, [online], http://adu.by/ $\mathrm{ru/homepage/prof-oby-1/inostrannyj-yazyk.html,} \mathrm{[dostęp:} \mathrm{01.10.2018].}$

Electronnye sredstva obucheniya po angliiskomu yazyku (profilnyeklassy), [online], http:// www.adu.by/ru/uchitelyu/sovremennye-sredstva-obucheniya-i-ikt-v-obr azovanii.html, [dostęp: 08.10.2018].

Avtorskiye kursy I.V. Zubrilinoy, [online], http://e-vedy.adu.by/course/index.php?cate goryid=67, [dostęp: 04.10.2018]. 